University of Wollongong

Research Online

Faculty of Business - Papers (Archive)

Faculty of Business and Law

2019

Institutional investors, controlling shareholders and CEO pay-performance relationship: evidence from China

Dan Zhang

University of Wollongong, dz495@uowmail.edu.au

Shiguang $\mathrm{Ma}$

University of Wollongong, shiguang@uow.edu.au

Xiaofei Pan

University of Wollongong, xpan@uow.edu.au

Follow this and additional works at: https://ro.uow.edu.au/buspapers

Part of the Business Commons

Research Online is the open access institutional repository for the University of Wollongong. For further information contact the UOW Library: research-pubs@uow.edu.au 


\title{
Institutional investors, controlling shareholders and CEO pay-performance relationship: evidence from China
}

\begin{abstract}
Using a large sample of China's listed firms between 2005 and 2015, we find that domestic mutual funds have a positive effect on the CEO pay-performance relationship, and this effect becomes stronger when their ownership is higher and closer to the controlling shareholder's ownership. This effect is stronger in non-state-owned enterprises (non-SOEs), firms facing weaker industry competition incentives, and firms located in more developed regions. However, Qualified Foreign Institutional Investors (QFIIs) do not have such an influence. Overall, our study contends that the effectiveness of institutional investors' monitoring role is subject to their identity, controlling shareholders and institutional environments.
\end{abstract}

\section{Keywords}

evidence, relationship:, pay-performance, china, ceo, institutional, shareholders, controlling, investors

Disciplines

Business

\section{Publication Details}

Zhang, D., Ma, S. \& Pan, X. (2019). Institutional investors, controlling shareholders and CEO

pay-performance relationship: evidence from China. Accounting and Finance, online first 1-32. 


\title{
Institutional investors, controlling shareholders and CEO pay- performance relationship: Evidence from China
}

\author{
Dan Zhang, Shiguang Ma, Xiaofei Pan \\ School of Accounting, Economics and Finance, University of Wollongong, \\ Wollongong, NSW, Australia
}

\begin{abstract}
:
Using a large sample of China's listed firms between 2005 and 2015, we find that domestic mutual funds have positive effect on CEO pay-performance relationship, and this effect becomes stronger when their ownership is higher and closer to the controlling shareholder's ownership. This effect is stronger in non-state-owned enterprises (non-SOEs), firms facing weaker industry tournament incentives, and firms located in more developed regions. However, Qualified Foreign Institutional Investors (QFIIs) do not have such an influence. Overall, our study contends that the effectiveness of institutional investors' monitoring role is subject to their identity, controlling shareholders and institutional environments.
\end{abstract}

Keywords: Institutional investors; CEO pay; Firm performance; China JEL: D21, G32, M21

The authors would like to express their thanks for comments from the editors and two anonymous referees, Chandrasekhar Krishnamurti, Haiyan Jiang, Terry Walter and other participants at the 2017 Financial Market and Corporate Governance (FMCG) conference and the seminar held at University of Wollongong. All remaining errors are our own. Please address correspondence to Xiaofei Pan via email: xpan@uow.edu.au 


\section{Introduction}

Over the past few decades, the growth of institutional investors has become a global phenomenon and they play an important role in mitigating information asymmetry and monitoring managers. ${ }^{1}$ This role became even more prominent after the 2008 global financial crisis when institutional investors were required to exert influence on management proposals including those related to CEO compensation (OECD, 2009).

Since then, a number of studies have revealed explicit evidence for the roles played by institutional investors in developed markets. They show that institutional investors are effective monitors and can mitigate information asymmetry. ${ }^{2}$ Meanwhile, other studies have examined the roles of institutional investors in emerging markets and document that institutional investors can affect firm performance/valuation (Yuan et al., 2008; Lin and Fu, 2017), the quality of financial reporting (Chan et al., 2014), firm innovation (Rong et al., 2017) and dividend policy (Firth et al., 2016; Cao et al., 2017). However, to the best of our knowledge, it is still unclear whether institutional investors could discipline managers' behaviors and influence the overall corporate governance in the interests of all the other minority shareholders. It is expected that this issue might be more prominent and relevant in emerging markets. On the one hand, the institutional environment is still underdeveloped and investor protection legislation is weaker in emerging markets. Thus, whether the expected functions of institutional investors can be ensured is unclear, as these concerns directly shape the incentives and behaviors of institutional investors. On the other hand, ownership concentration is usually a prevalent aspect in emerging markets, and controlling shareholders usually make the final decisions regarding firm policies. Institutional investors may have been captured by controlling shareholders and thus their independence is compromised, so their monitoring role is no longer as straightforward.

In this study, we empirically examine whether and how institutional investors monitor CEO compensation in China, the largest emerging market. Our study is motivated by several strands of literature. First, a series of studies suggest that institutional investors can potentially affect corporate compensation schemes (Hartzell and Starks, 2003; Croci et al., 2012; Cheng et al., 2015; Golebiowska and Urbanek, 2016), and these impacts are different due to differing investment horizons, the cost of monitoring, and the business relationships with their portfolio firms (Chowdhury and Wang, 2009; Shin and Seo, 2011; Zhu et al., 2017). Since these studies mainly focus on developed markets, it is really unknown whether it is the case in China with

\footnotetext{
${ }^{1}$ See, for example, Hartzell and Starks (2003), Aggarwal et al. (2005), Shin and Seo (2011), Helwege et al. (2012), Boone and White (2015), Bena et al. (2017) and Chen and Keung (2018).

${ }^{2}$ See, for example, Koh (2007), Ferreira and Matos (2008), Boehmer and Kelley (2009), Fich et al. (2015), Cornett et al. (2007) and Borochin and Yang (2017).
} 
poor investor protection and prevailing ownership concentration.

Second, it has been argued that the role of shareholders is mainly attributed to their identities (Shleifer and Vishny, 1997; Cronqvist and Fahlenbrach, 2008; Lin et al., 2011), so a more rigorous investigation of institutional investor heterogeneity is required. In China's stock markets, there are various kinds of institutional investors with different ownership identities, such as private institutions, governments, and foreign institutions. This setting can thus provide a sufficient tension where the different monitoring roles exerted by various types of institutional investors can be investigated.

Third, existing studies document that if firms have several shareholders with substantial ownership, they have the incentive to monitor the controlling shareholders to reduce the associated expropriation and moral hazard activities (Bennedsen and Wolfenzon, 2000; Laeven and Levine, 2008; Jiang et al., 2018). However, it is unclear whether the effectiveness of monitoring by other large shareholders can be attributed to the identities of controlling shareholders. Chinese listed firms can be divided into state-owned enterprises (SOEs) and nonSOEs, and these controlling shareholders have different incentives for monitoring CEO compensation (Kato and Long, 2006; Cao et al., 2011). In the spirit of these studies, we further investigate how institutional investors respond to controlling shareholder's ownership.

It has been argued that CEO compensation incentives are not only determined by observed CEO characteristics, but also determined by unobserved characteristics such as CEO psychological traits and personality. Coles and Li $(2016,2018)$ further document that these unobserved CEO characteristics can better explain the variations of CEO pay-performance sensitivity. Therefore, in our empirical analysis, we employ firm-fixed effects model as estimation method to address this concern. Using a sample of Chinese listed firms from 2005 to 2015 , we obtain the following findings. First, the presence of domestic mutual funds can strengthen the relationship between CEO pay and firm accounting performance (measured by ROA), and such positive effects are stronger when their ownership becomes closer to that of the controlling shareholders. However, Qualified Foreign Institutional Investors (QFIIs) wield no significant effects on the CEO pay-performance relationship. Second, empirical results show that the positive effects of domestic mutual funds are more pronounced in non-SOEs than in SOEs, particularly the central government controlled SOEs. Third, additional analysis reveals that the positive effects of domestic mutual funds are stronger in firms located in more developed regions or in firms with weaker industry tournament, which supports the assertion that mutual funds strengthen the CEO pay-performance relationship by improving corporate governance. Furthermore, when we use annual stock returns and Tobin's Q to measure firm performance, the effects of institutional investors on the relationship between CEO pay and 
firm performance become insignificant. These results indicate that institutional investors have weaker incentives to link CEO pay to market performance. These results are robust when taking the potential endogeneity into consideration and using alternative measures of executive compensation.

Our study makes several contributions to existing literature. First, over the last decade many studies have examined shareholder activism by institutional investors in developed markets (Smith 1996; Cvijanović et al., 2016; Gillan and Starks, 2000). There are also a large number of studies investigating the influence of institutional investors in emerging markets (e.g., Yuan et al., 2008; Firth et al., 2016; Lin and Fu, 2017; Rong et al., 2017). But these studies on emerging markets only examine the effects of institutional investors' activism on firm performance or firm policies (eg., dividend policy) that could benefit institutional investors directly (Firth et al., 2016). As a complement to these studies, our study examines how institutional investors affect corporate governance, in particular the CEO pay-performance relationship in China. Moreover, studies from developed countries or international markets document that foreign institutional investors have a positive effect on enhancing corporate governance (Ferreira and Matos, 2008; Luong et al., 2017), whereas our study finds some contrasting evidence that QFIIs exert no significant effect on corporate governance in China due to its different and unique culture (a relationship-based economy), different dialects and government intervention in the economy. This study therefore advances our understanding of the real effects that domestic and foreign institutional investors have on corporate governance.

Second, our work builds on literature that examines shareholders' influence on corporate governance (Laeven and Levine, 2008; Attig et al., 2009). By focusing on the institutional investors who are usually non-controlling shareholders, we provide direct evidence that their influence on the CEO pay-performance relationship depends largely on their relative ownership to controlling shareholders, which is consistent with arguments made by Firth et al. (2010) and Huang and Zhu (2015). We find that the monitoring effects of institutional investors depend on their ownership, as well as the difference in ownership compared to controlling shareholders.

Third, our study also adds to literature that examines the effect of identity of shareholders on the CEO pay-performance relationship (Kato and Long, 2006; Conyon and He, 2011). From the perspective of ownership types, we examine the effects of institutional investors by distinguishing different types of owners because this is relevant to their behaviors and provides evidence of how comprehensive institutional investors work in emerging markets.

The remainder of the paper is organized as follows. Section 2 describes the background information of institutional investors in China and develops hypotheses. Section 3 introduces the data and method of analysis. Section 4 presents our empirical results and finally, section 5 
draws some conclusions.

\section{Background and hypotheses development}

\subsection{Development of institutional investors in China}

It is about two decades since institutional investors emerged in China and they have now become important market participants. In 1997, the government issued the 'Interim measures for the administration of securities investment funds' (amended in 2012), which formally allows institutional investors to trade common shares on China's stock exchanges. Since then the domestic mutual funds have grown quickly. For example, there were only 10 fund management companies managing 23 mutual funds in 1999, but in 2015 there are 97 fund management companies managing 2,676 mutual funds. The size of mutual funds grew steadily from 51.42 billion RMB at the end of 1999 to $4,470.68$ billion RMB by the end of $2015 .{ }^{3}$ Domestic mutual funds are now playing a "pillar role" of institutional investors in China.

To further promote the development of the stock markets, the People's Bank of China (the central bank in China) and China Securities and Regulatory Commission (CSRC) jointly issued (in 2002) the 'Measures for the administration of domestic securities investment of Qualified Foreign Institutional Investors (QFIIs)' (amended in 2006), which formally introduced qualified foreign institutional investors to the Chinese stock exchanges. The number of QFIIs has increased substantially such that there were 12 QFIIs by the end of 2003, and 291 by the end of October 2015.

In addition to domestic mutual funds and QFIIs, there are other types of institutional investors simultaneously and actively investing in the Chinese stock market such as banks, insurance companies, social security funds, brokers, entrust companies, and financial companies. These institutional investors are usually passive investors who hold their ownership due to business connections with firms. For instance, in line with the Commercial Bank law, since 2003, banks can only hold shares which are pledged by firms as collateral for bank loans. Thus, these institutional investors wield less exit threats because they mainly benefit from business with firms rather than an increase in the value of the equity they hold.

\subsection{Institutional investors and CEO pay-performance in China}

In the spirit of Shleifer and Vishny (1997), the incentive and behaviors of institutional investors depend largely on their identities. It is thus of great significance to distinguish the types of institutional investors for investigating their effects in the investee firms (Borochin and Yang, 2017). According to what we described in the above section, we mainly identify both

\footnotetext{
${ }^{3}$ At the end of 1999, the exchange rate between USD and CNY is CNY8.279/USD. At the end of 2015, the exchange rate between USD and CNY is CNY6.494/USD.
} 
domestic mutual funds and QFIIs.

It has been well documented that institutional investors serve the monitoring role in mitigating the agency problem between managers and shareholders, thus improving the CEO pay-performance sensitivity (Hartzell and Starks, 2003; Almazan et al., 2003). Domestic mutual funds in China are controlled by domestic private institutions whose main objective is to maximize portfolio returns. Moreover, domestic mutual funds are becoming large, betterinformed and more active shareholders. Therefore, domestic mutual funds are similar to their counterparts in developed markets and are able to exert influence on firms' decisions. We expect that domestic mutual funds have positive effects on the CEO pay-performance relationship for the following several reasons.

First, domestic mutual funds do not have business connections with their portfolio firms, so their monitoring activities are less sensitive to pressure and face less conflict of interest with their portfolio firms (Yuan et al., 2008; Liu et al., 2014). Thus, domestic mutual funds have strong incentives to restrain managerial opportunistic behaviors and impose a strong dependence of CEO pay on firm performance (Cornett et al., 2007). Moreover, since domestic mutual funds hold a relatively large percentage of shares, they can also place more exit threat on investee firms by voting with their feet. For this reason the board prefers to make decisions that favor mutual funds.

Second, the compensation of mutual funds' managers is not only related to their funds' size but also linked to the incremental value of their funds' assets (shares), which directly reflect the performance of the investee firms. So mutual funds' managers are concerned about the performance of their investee firms and are likely to impose disciplinary activities over CEOs.

Third, professional skills in analyzing information enable investors to influence firms (Borochin and Yang, 2017; Jiang and Yuan, 2018). Domestic mutual funds are considered to have expertise and are professional in gathering and processing information. Their professional information processing helps mitigate information asymmetry between managers and shareholders, which makes it easier for shareholders to monitor managers' behavior (Hartzell and Starks, 2003). There is a suspicion that transient investors have short investment horizons and consequently are unlikely to collect and analyze firm information. However, we argue that transient investors could benefit from private information, as collecting/analyzing private information enables them to trade ahead of firm-specific news and gain from short-term price movements or avoid sudden loss (Boone and White, 2015).

Fourth, domestic mutual funds have reputational concerns because they are usually expected to be monitors in firms. It is generally agreed that a weaker association between CEO pay and firm performance signals a weak corporate governance and poor monitoring system 
towards the stock markets. Therefore, a weaker relationship between CEO pay and firm performance may lead to the reputational detriment of domestic mutual funds. To protect their reputation, domestic mutual funds tend to strengthen the CEO pay and performance relationship, so we form the following hypothesis:

Hla: Domestic mutual funds have positive effects on the CEO pay-performance relationship.

With respect to QFIIs which are owned by foreigners, it has been extensively documented that they are also effective monitors of firm management by providing more sophisticated knowledge and advanced management skills (Ferreira and Matos, 2008; Huang and Zhu, 2015; Firth et al., 2016; Bena et al., 2017). However, because QFIIs are less familiar with the unique institutional environment of China, such as relationship-based economy, many regional dialects spoken and different accounting standards (Liu et al., 2014; Zou et al., 2016; Luong et al., 2017), they do not have the ability to handle issues with their invested firms in comparison with their domestic counterparty - domestic mutual funds. We propose that the expected significant and beneficial effects of QFIIs on enhancing the positive relationship between CEO pay and firm performance could be seriously compromised for the reasons set out below.

First, unlike developed countries, information asymmetry is severe in China's market due to both insider control and weak requirement for disclosure (Yuan et al., 2009). In the spirit of Bae et al. (2008) and Ferreira et al. (2017), foreign investors may be less informed about China's firms than domestic investors. Coupled with the fact that the Chinese language is not spoken worldwide (Liu et al., 2014), QFIIs are less efficient at processing and comprehending information and thus face more severe information asymmetry when investing in China.

Second, the Chinese economy is highly controlled by the central and local governments and imbedded within a culture traditionally based on relationships, which means that the key element to success in business is to build and maintain a relationship with government (Shen et al., 2019; Li et al., 2017; Wu et al., 2012; Liu et al., 2014). Unlike domestic investors, it is harder for foreign investors to cooperate with China's regulators or establish valid connections with government representatives, and this may undermine their expected efficient monitoring. If these two reasons are combined, we conjecture that QFIIs may have a weaker effect on enhancing the CEO pay-performance relationship:

HIb: QFIIs may have weaker effects on the CEO pay-performance relationship.

Moreover, an evolving literature on multiple large shareholders (MLS) asserts that other large shareholders can serve efficient monitoring in curbing the expropriation by controlling shareholders, achieved through forming coalitions with other large stakeholders or competing for control by attracting minority shareholders. This becomes stronger when the ownership held 
by these large shareholders is closer to the ownership held by the controlling shareholders (Bennedsen and Wolfenzon, 2000; Maury and Pajuste, 2005; Laeven and Levine, 2008; Attig et al., 2008, 2009; Mishra, 2011; Ben-Nasr et al., 2015; Jiang et al., 2018). In China, ownership of a business is usually concentrated in the hands of controlling shareholders, and domestic mutual funds are usually other large shareholders. Thus, the monitoring influence of domestic mutual funds is also subject to the balance of power between their ownership and that of controlling shareholders. Following the MLS literature, we conjecture that when domestic mutual funds present as one of the large shareholders and hold closer ownership to that of the controlling shareholders, they are more likely to better monitor the CEO pay-performance relationship. Therefore, we put forward the following hypothesis:

H2: The positive effect of domestic mutual funds on the CEO pay-performance relationship is stronger when the difference in ownership between domestic mutual funds and the controlling shareholders decreases.

\subsection{The effect of institutional investors in SOEs and non-SOEs}

According to the above discussion, the effect of institutional investors is more likely to be captured by controlling shareholders, so we also conjecture that the effects that institutional investors have on the CEO pay-performance relationship are subject to the types of controlling shareholders. Chinese listed firms can be divided into state-owned enterprises (SOEs) and nonSOEs (Peng et al., 2017). SOEs are controlled by different levels of government (Kong et al., 2019). Multi-task theory contends that SOEs function more like the institutions of governments and seek to achieve multiple objectives such as improving production, maintaining social stability and keeping employment (Chang and Wong, 2009; Fan et al., 2013). Therefore, CEO pay in SOEs does not dependent solely on firm performance, which weakens the relationship between CEO pay and firm performance. Moreover, CEOs in Chinese SOEs have other incentives to consider such as political promotion which also weakens the relationship between CEO pay and firm performance. However, non-SOEs are controlled by private sector entities who strive to maximize firm value and face less government intervention when making decisions (Chen et al., 2011). This requires a stronger relationship between CEO pay and firm performance in non-SOEs, which provides sufficient incentive for CEOs to perform well.

In addition, since 1978, Chinese SOEs have experienced a series of privatization and corporatization reforms when the government awarded sufficient autonomy to enterprises and relinquished its control over some SOEs to a large extent. Consequently, SOEs are becoming market-oriented and aim to maximize profitability, and compensation of executives in SOEs is becoming more aligned to profits and sales. However, this is more likely to be the case in those 
SOEs controlled by the local governments (Chen et al., 2009; Cao et al., 2011), rather than in those SOEs controlled by the central government. In particular, central SOEs are still under the absolute control of the government which has certain political and strategic objectives, such as maintaining its monopoly over some sensitive industries. So their CEO compensation incentives are determined by the government, and less likely to be influenced by the institutional investors. In this sense, we expect that institutional investors can affect the CEO pay-performance relationship in local SOEs, but have no effect on the CEO pay-performance relationship in central SOEs. Therefore, we form the following hypothesis:

H3: The influence of domestic mutual funds on the CEO pay-performance relationship is stronger in non-SOEs than in SOEs, particularly central government controlled SOEs.

\section{Data and methodology}

\subsection{Data and sample selection}

The sample of empirical analysis includes firms listed on the Shanghai Stock Exchange (SHSE) and the Shenzhen Stock Exchange (SZSE) from 2005 to 2015. Our sample year starts from 2005 when individual executive compensation began to be disclosed in annual reports, but only the total compensation received by the top three executives was reported before 2005 . From the total population of firms, we exclude those flagged with ST and *ST (Special Treatment), firms from the finance industry and firms with missing information. The final sample consists of 1,960 firms and 15,613 firm-year observations. All the data are collected from the Chinese Stock Market and Accounting Research (CSMAR) database.

\subsection{Institutional investors and ownership measurements}

Empirically, we apply three dimensions to measure institutional investors' ownership. First, we consider whether a firm has institutional investors as common shareholders and then create two dummy variables, Mutuald and QFIId, which are equal to 1 if a firm has domestic mutual funds and QFIIs as the common shareholders, respectively, and 0 otherwise. Second, we consider the level of ownership held by institutional investors and then create two continuous variables, Mutual and QFII, which are defined as the percentage of ownership held by domestic mutual funds and QFIIs, respectively. Third, we consider the difference in ownership between institutional investors and controlling shareholders and then create two continuous variables, Mutualratio and QFIIratio, which are defined as the ratio of ownership held by domestic mutual funds and QFIIs to the ownership held by the controlling shareholders, respectively. The higher these two ratios are, the smaller the difference in ownership between institutional investors and controlling shareholders is. 


\subsection{Model}

In our empirical analysis, we use the following regression equation to examine the effects of institutional investors on the CEO pay and firm performance relationship, which is reflected by the coefficients of interactive terms:

$$
\begin{aligned}
\text { CEOpay }_{i t}= & \beta_{0}+\beta_{1} \text { Mutual }_{i, t}+\beta_{2} \text { QFII }_{i, t}+\beta_{3} \text { ROA }_{i, t-1}+\beta_{4} \text { Mutual }_{i, t} * \text { ROA }_{i, t-1} \\
& +\beta_{5} \text { QFII I }_{i, t} * \text { ROA }_{i, t-1}+\beta_{6} \text { Others }_{i, t}+\beta_{7} \text { Size }_{i, t}+\beta_{8} \text { Lev }_{i, t}+\beta_{9} \text { Board }_{i, t}+\beta_{10} \text { Indep }_{i, t} \\
& +\beta_{11} \text { Largest } \beta_{12} \text { CEOage }+ \text { Dummy }(\text { year })+\varepsilon_{i t}
\end{aligned}
$$

where CEOpay represents the compensation of CEOs as measured by the natural log of CEO's total cash compensation, which is the sum of salary, bonus and other cash compensation. Mutual and QFII represent domestic and foreign institutional ownerships, respectively, which are discussed in section 3.2. ROA is return on assets calculated as the ratio of net income to total assets, which serves to measure firm performance. To reflect the logical influence of performance on CEO pay, we use one-year lagged performance as an independent variable in the regression analysis so that the sample size for the regression analysis should be reduced. $\beta_{4}$ and $\beta_{5}$ are used to test our main hypotheses. According to our discussions, $\beta_{4}$ is expected to be significantly positive and $\beta_{5}$ is expected to be insignificant.

To consider the effects of other variables on CEO pay, we also include a set of control variables, namely firm size, leverage level and board characteristics. The definitions of all the variables in this study are listed in Appendix A. Year dummy is also included to control for time-series effects. According to the studies by Coles and Li $(2016,2018)$, unobserved CEO characteristics also have significant effect on CEO pay-performance relationship. Thus, we estimate equations with firm fixed effects to address this issue.

We have to acknowledge that current literature also uses delta to measure the CEO payperformance sensitivity (Coles et al., 2006; Babenko 2009; Dang et al., 2018). However, in our sample of Chinese firms, there are only 127 firms granting stock options to CEOs. Due to the small sample disproportionate our investigated population, we are unable to obtain meaningful results using delta to measure the CEO pay-performance sensitivity. Moreover, the data we obtained from the CSMAR database is limited, so that we are not able to calculate the value of stock options using the Black-Scholes model indicated by the delta definition. In addition, it has been argued that Chinese stock market is influenced by various factors including government manipulation, which makes stock price too noisy to measure firm performance (XXX). Therefore, we do not use the delta to measure the CEO pay-performance sensitivity in this study. 


\section{Empirical Results}

\subsection{Summary statistics}

Table 1 provides summary statistics of the sample. The average CEO pay is 480,899 RMB, which is almost six times more than that from 1998 to 2000 (Firth et al., 2007). The average ownership of domestic mutual funds and QFIIs are $4.189 \%$ and $1.254 \%$, respectively, and the results are in line with Firth et al. (2016). The summary of Mutuald and QFIId shows that in our sample, $62.7 \%$ of firms have domestic mutual funds as shareholders and $9.9 \%$ of firms have QFIIs as shareholders. This indicates that institutional ownership is quite common in the Chinese equity market. Based on average board size (9.057) and the number of independent directors (3.274), the percentage of independent directors can be obtained, which is $36.15 \%$. The average percentage of shares held by the largest shareholders is $36.602 \%$, which reflects a high level of ownership concentration in Chinese firms. Moreover, the percentage of observations for non-state-owned firms is $42.855 \%$.

\section{[Insert Table 1 here]}

\subsection{Effects of institutional ownership on the CEO pay-performance relationship}

Table 2 presents the results from testing our main hypotheses. Specifically, column (1) shows the results of focusing on whether there are institutional investors as shareholders. Column (2) shows the results of focusing on institutional investors' ownership, while column (3) shows the results of focusing on the difference between institutional investors' ownership and controlling shareholder's ownership. We are concerned about the interactive terms because they reflect the effects that institutional investors have on the CEO pay-performance relationship. As shown in columns (1) and (2), the coefficients of Mutuald ${ }^{*} R O A(0.686)$ and Mutual*ROA (8.454) are both positive and statistically significant at the $1 \%$ level, which indicates that the presence of domestic mutual funds helps to link CEO pay to firm performance, and this effect becomes stronger when domestic mutual funds hold a larger percentage of shares. This result is consistent with our H1a. We also find that the coefficients of $Q F I I d^{*} R O A$ and $Q F I I^{*} R O A$ are positive but insignificant, which implies that QFIIs do not have significant effects on the CEO pay-performance relationship. This is consistent with our hypothesis H1b.

Column (3) shows that the coefficient of Mutualratio*ROA is 1.556 and significant at the $1 \%$ level (t-value is 3.38), while the coefficient of QFIIratio*ROA is insignificant. This suggests that the previously documented strengthening effects of domestic mutual funds become even stronger when their ownership is closer to the controlling shareholder's ownership. This finding is consistent with our $\mathrm{H} 2$. The results of the relationship between control variables and CEO pay are consistent with previous studies (Firth et al., 2007). 
Overall, the existence of domestic mutual funds can improve corporate governance by strengthening the CEO pay-performance relationship. When the ownership of domestic mutual funds is closer to the controlling shareholders and present as large shareholders, their influence becomes stronger as a result of the strong incentive to contend with controlling shareholders. However, due to the challenges/obstacles that are unique to China's culture (such as relationship-based economy and various languages spoken within the country), QFIIs cannot improve corporate governance due to an inability to improve their monitoring performance.

\section{[Insert Table 2 here]}

\subsection{Effects of institutional ownership between SOEs and non-SOEs}

In this section, we test hypothesis H3 by dividing our sample firms into SOEs and nonSOEs. A firm is identified as an SOE if the ultimate controlling shareholder is the government. Empirically, we re-estimate equation (1) using separate subsamples of SOEs and non-SOEs, and report the results in Table 3. Specifically, columns (1) to (3) are the results of using a subsample of SOEs, and columns (4) to (6) are the results of using a subsample of non-SOEs. Again, we are concerned about the interactive terms. It is observed that the coefficient of Mutuald*ROA is 0.533 for SOEs, which is significant at the $5 \%$ level (t-value is 2.17 ), and 0.944 for non-SOEs, which is significant at the $1 \%$ level (t-value is 3.60). The coefficient of Mutual $* R O A$ is 7.481 for SOEs, which is significant at the $5 \%$ level (t-value is 2.40), and 11.926 for non-SOEs, which is significant at the $1 \%$ level ( $\mathrm{t}$-value is 3.92 ). These results suggest that domestic mutual funds can strengthen the CEO pay-performance relationship, and this is more significant in non-SOEs as reflected by the larger magnitude of coefficients for non-SOEs.

The different effects that domestic mutual funds have in SOEs and non-SOEs are more obvious when the difference in ownership between them and controlling shareholders is considered. In particular, column (3) shows that the coefficient of Mutualratio*ROA is 1.405 in SOEs, which is significant at only $10 \%$ level ( $\mathrm{t}$-value is 1.81 ); while it is 2.292 for non-SOEs in column (6), which is significant at $1 \%$ level (t-value is 4.32 ). This suggests that when the ownership of domestic mutual funds is closer to that of controlling shareholders, the incentive of domestic mutual funds to contend with controlling shareholders is stronger in non-SOEs. This is reflected by the more significant and larger coefficient of Mutualratio*ROA for nonSOEs. The Chow tests $(\mathrm{F}=5.205, \mathrm{p}$-value $<0.01 ; \mathrm{F}=5.327, \mathrm{p}$-value $<0.01 ; \mathrm{F}=5.293$, $\mathrm{p}$ value $<0.01$ ) reveal that the effects of domestic mutual funds are stronger on the CEO payperformance relationship in non-SOEs than SOEs.

To further test H3, we re-estimate equation (1) using subsamples of central government controlled SOEs and local government controlled SOEs. The results are reported in Table 4. It 
is observed that in columns (1) to (3), the coefficients of all the interactive terms between mutual funds' ownership measure and ROA are insignificant. This means that mutual funds have no significant effects on the CEO pay-performance relationship in central government controlled SOEs. However, the results in columns (4) to (6) reveal that the coefficients of interactive terms between mutual funds' ownership measure and ROA are significantly positive. This suggests that mutual funds have significant effects on the CEO pay-performance relationship in local government controlled SOEs. These results validate hypothesis H3. These results are also consistent with Firth et al. (2010) who argue that domestic mutual funds face pressure and regulation from local governments, so the effect of domestic mutual funds is mitigated and they are less likely to contend with governments in SOEs.

\section{[Insert Table 3 here] \\ [Insert Table 4 here]}

\subsection{Endogeneity issues, additional evidence and robustness tests}

\subsubsection{Endogeneity issues}

Although we have used firm fixed effects to address the potential endogeneity issue, our study faces a potential issue of sample selection bias as institutional investors may prefer particular firms or industries. To address this issue, we use the Heckman two-stage method. The first stage involves an OLS analysis where institutional ownership is regressed against the same control variables from the main equation. To meet the exclusion restrictions, we also include three variables that we do not include in the second-stage regression. The first two variables are the industry median level of mutual funds and QFIIs. The third variable is a dummy variable which captures the index inclusion of a firm, following Firth et al. (2016) and Rong et al. (2017). In particular, this variable is Index which is equal to 1 if a firm is included in either the Shanghai 180 index or Shenzhen Component index in a year and 0 otherwise. We then obtain the inverse Mills ratios (Lambda) from the first stage and include them as independent variables in the second stage.

Furthermore, we use the PSM method to construct a sample in which the treatment sample and control sample are similar in terms of some observed characteristics. In this matching process, for each firm-year observation in the treatment sample (i.e., those observations with either domestic mutual funds or QFIIs as shareholders), we identify an observation in the control sample (i.e., those observations without either domestic mutual funds or QFIIs as shareholders) with the same/nearest propensity score of firm characteristics including firm size, 
leverage, board size, board independence, the largest shareholder's ownership, and CEO age in the same year from the same industry.

The results of using the Heckman two-stage method and PSM are reported in Table 5, which are quite similar to those reported in Table 2, indicating that our main results are robust after considering the potential endogeneity issues using alternative estimation methods.

\section{[Insert Table 5 here]}

Moreover, it could be also argued that institutional investors prefer investing in firms with a strong CEO pay-performance relationship, which results in reverse causality. To address this issue, we examine changes in the CEO pay-performance relationship when institutional investors sell their holding firms ownership. ${ }^{4}$ The results show that the increase (decrease) of mutual funds' ownership strengthens (weakens) the pay-performance relationship. In order to save space, we do not report the related results, but they are available on request.

\subsubsection{Corporate governance channel}

We have previously argued that mutual funds strengthen CEO pay-performance by monitoring CEOs' behaviors and improving corporate governance. In this section, we provide empirical evidence to validate that corporate governance is the channel through which mutual funds can affect CEO pay-performance. ${ }^{5}$ To measure the level of corporate governance, we use the industry tournament incentives, since it is argued that strong industry tournament provides effective incentives for CEOs (Coles et al., 2018). In particular, we use the compensation gap between CEO in a firm and the highest paid CEO among firms operating in the same industry to measure industry tournament. We then divide sample firms into two groups based on the median value of industry tournament, and re-estimate equation (1) using these two subsamples and report the results in Table 6. As can be seen from the results, the coefficients of interaction terms of mutual funds' ownership and firm performance are more significant in firms with less intensive product market competition and in firms with weaker industry tournament. These results support our argument that mutual funds affect CEO pay-performance via improving corporate governance.

\section{[Insert Table 6 here]}

Moreover, there may be some other potential channels through which mutual funds have influence on CEO compensation. For instance, Li et al. (2019) document that mutual funds are

\footnotetext{
${ }^{4}$ We thank the referee for this suggestion.

${ }^{5}$ We thank the referee for this suggestion.
} 
likely to require a stronger relationship between CEO pay and firm CSR outcomes, and firm CSR outcomes are determined by mutual fund's CSR score. Their study indicates that mutual funds' self-attributes affect their incentives for monitoring and improving corporate governance, which is a key channel for mutual funds to affect CEO pay-performance relationship. However, due to the data unavailability, we are not able to test this potential channel empirically at the moment, but we call for future studies on this important issue.

\subsubsection{Effects of regional development}

Whether or not the function of institutional investors can be guaranteed depends mainly on the development of a legal system and investor protection. The laws and regulations in more developed regions could be better enforced which would protect investors' interests. Moreover, information asymmetry is believed to be more severe in firms from less developed regions, which makes it difficult for institutional investors to know what is happening through investee firms and to monitor effectively. Thus, we propose that institutional investors have a greater effect in firms located in more developed regions. To test this conjecture, we take advantage of the regional variations in China's economic development to examine the different influences of institutional investors. We do this by dividing the full sample into two groups of firms located in more and less developed regions. All the regions are divided into more developed and less developed based on the Chinese marketization index (Fan et al., 2011) which measures the marketization levels of 31 provinces. We define the provinces ranking the top 15 as being more developed and all the others as less developed.

Empirically, we estimate equation (1) using subsamples of firms located in more and less developed regions separately. The results are reported in Table 7. Consistent with the structure in Table 6, columns (1) to (3) are the results of using a subsample of firms located in more developed regions, and columns (4) to (6) are the results of using a subsample of firms located in less developed regions. Again, we are concerned about the coefficients of interactive terms. Note that the coefficients of Mutuald*ROA, Mutual*ROA and Mutualratio*ROA are positive and statistically significant for firms from more developed regions, while they are insignificant for firms from less developed regions. These findings suggest the effects of domestic mutual funds on strengthening the CEO pay-performance relationship are stronger in firms from more developed regions. Note also that all the coefficients of interactive terms related to QFIIs are not significant in firms from either more or less developed region, which confirms our previous findings that QFIIs have no significant effect. These results support our argument that the function of institutional investors can only be ensured when their interests/rights are well protected, when the legal system is developed, and when regulations are properly enforced. 


\section{[Insert Table 7 here]}

\subsubsection{Robustness tests}

In this section, we conduct a further analysis to check the robustness of our main results. First, we consider two alternative measures of CEO compensation to check the robustness of our main results by: (1) including CEO ownership values; and (2) using the average compensation of the top three executives. Harford and $\mathrm{Li}$ (2007) argue that managerial ownership and its relationship with the firm performance could be used as an indication of good governance. In spirit of their study, we are thus interested in examining whether CEO pay, including the value of their shareholding, is positively related to firm performance, which is due to the monitoring by institutional investors. Following the method used by Bergstresser and Philippon (2006), we calculate the value of CEO ownership as the number of common shares held by CEOs at the end of the fiscal year, multiplying the closing prices of the common shares at the end of the fiscal year. The results are reported in Table 8.

\section{[Insert Table 8 here]}

Second, we consider an alternative measure of firm performance which is market-based. This is mainly because institutional investors are expected to maximize the return of their investment portfolios via appreciations in stock price so they might have incentives to link CEO pay to market-based performance. To provide empirical evidence for this conjecture to be tested, we employ annual stock returns (RET) and Tobin's Q as the proxies for firm market performance, and then re-estimate equation (1). The untabulated results indicate that both domestic mutual funds and QFIIs have no significant effects on linking CEO pay to firm market performance. This suggests that in China, institutional investors are more concerned about the accounting performance of investee firms than market performance. One possible explanation could be that since the Chinese stock market is influenced by many factors such as government manipulation, stock returns are too noisy to measure firm performance accurately. For example, China's Gross Domestic Product (GDP) was $\$ 1,211$ billion in 2000 and $\$ 12,237$ billion in 2017, which means that it increased by $14.57 \%$ each year. Meanwhile, the Shanghai Stock Exchange index was 1408 in 2000 and 3196 in 2017, representing an increase of 4.9\% per year. Obviously, market performance cannot reflect accounting performance. Therefore, the accounting measures are most likely to reflect firm performance and applied by investors to assess firm value.

Moreover, to further test the robustness between institutional ownership and CEO payperformance relationship, we re-estimate equation (1) by using one-year lagged institutional ownership and control variables. The results further validate the causality issue between mutual 
funds' ownership and CEO pay-performance relationship. To save space, the results in this section are not reported but are available on request.

\section{Conclusion}

Using a sample of China's listed firms from 2005 to 2015, this paper examines the effect of institutional investors on the relationship between CEO pay and firm performance. The empirical results indicate that domestic mutual funds play an important monitoring role in linking CEO pay to firm performance. Moreover, this monitoring effect is stronger when mutual fund ownership is larger and closer to controlling shareholder's ownership. However, QFIIs do not have such an effect on the CEO pay-performance relationship. These results are robust to alternative estimation methods in addressing endogeneity issues and using alternative measures for our key variables.

Moreover, the effects of domestic mutual funds are more pronounced in non-SOEs and local government controlled SOEs than in central government controlled SOEs. We also provide strong evidence that mutual funds affect CEO pay-performance by improving corporate governance. In particular, the positive effect of mutual funds is more significant in those firms with weaker industry tournament. Meanwhile, the monitoring role of domestic mutual funds is stronger in firms from more developed regions due to better investor protection and less information asymmetry.

Overall, institutional investors reveal heterogeneous influences on monitoring firm management in China, which advances our understanding of the importance to identify the types of institutional investors when investigating their influence. Our results show that in China with many dialects and a relationship-based economy, foreign investors face severe information asymmetry problems and are less efficient in monitoring, suggesting that further regulatory efforts are required to protect foreign investors' rights and reinforce their function in improving corporate governance in China. As a more important implication, our study suggests that considering the influence of controlling shareholders can shed more light on understanding the effect of involving institutional investors in corporate governance practices in China. 


\section{References}

Aggarwal, R., Klapper, L., Wysocki, P. D., 2005. Portfolio preferences of foreign institutional investors. Journal of Banking and Finance 29(12), 2919-2946.

Almazan, A., Hartzell, J., Starks, L., 2005. Active institutional shareholders and costs of monitoring: Evidence from executive compensation. Financial Management 34(4), 534.

Attig, N., El Ghoul, S., Guedhami, O., 2009. Do multiple large shareholders play a corporate governance role? Evidence from East Asia. Journal of Financial Research 32(4), 395422.

Attig, N., Guedhami, O., Mishra, D., 2008. Multiple large shareholders, control contests, and implied cost of equity. Journal of Corporate Finance 14, 721-737.

Babenko, I., 2009. Share repurchases and pay-performance sensitivity of employee compensation contracts. The Journal of Finance 64(1), 117-150.

Bae, K.-H., Stulz, R. M., Tan, H., 2008. Do local analysts know more? A cross-country study of the performance of local analysts and foreign analysts. Journal of Financial Economics 88(3), 581-606.

Bena, J., Ferreira, M. A., Matos, P., Pires, P., 2017. Are foreign investors locusts? The longterm effects of foreign institutional ownership. Journal of Financial Economics 126(1), 122-146.

Ben-Nasr, H., Boubaker, S., Rouatbi, W., 2015. Ownership structure, control contestability, and corporate debt maturity. Journal of Corporate Finance 35, 265-285.

Bennedsen, M., Wolfenzon, D., 2000. The balance of power in closely held corporations. Journal of Financial Economics 58(1), 113-139.

Bergstresser, D., Philippon, T., 2006. CEO incentives and earnings management. Journal of Financial Economics 80(3), 511-529.

Boehmer, E., Kelley, E. K., 2009. Institutional investors and the informational efficiency of prices. Review of Financial Studies 22(9), 3563-3594.

Boone, A. L., White, J. T., 2015. The effect of institutional ownership on firm transparency and information production. Journal of Financial Economics 117(3), 508-533.

Borochin, P., Yang, J., 2017. Options, equity risks, and the value of capital structure adjustments. Journal of Corporate Finance 42, 150-178.

Cao, L., Du, Y., Hansen, J. Ø., 2017. Foreign institutional investors and dividend policy: Evidence from China. International Business Review 26(5), 816-827.

Cao, X., Pan, X.,Tian, G., 2011. Disproportional ownership structure and pay-performance relationship: Evidence from China's listed firms. Journal of Corporate Finance 17, 541554.

Chan, A. L.-C., Ding, R., Hou, W., 2014. Does mutual fund ownership affect financial reporting quality for Chinese privately-owned enterprises? International Review of Financial Analysis 36, 131-140.

Chang, E. C., Wong, S. M., 2009. Governance with multiple objectives: Evidence from top executive turnover in China. Journal of Corporate Finance 15(2), 230-244.

Chen, G., Keung, E., 2018. Corporate diversification, institutional investors and internal control quality. Accounting and Finance 58 (3), 751-786.

Chen, C. J. P., Li, Z., Su, X., Sun, Z., 2011. Rent-seeking incentives, corporate political connections, and the control structure of private firms: Chinese evidence. Journal of Corporate Finance 17(2), 229-243.

Chen, G., Firth, M., Xu, L.P., 2009. Does the type of ownership control matter? Evidence from China's listed companies. Journal of Banking and Finance 33 (1), 171-181.

Cheng, M., Lin, B., Wei, M., 2015. Executive compensation in family firms: The effect of multiple family members. Journal of Corporate Finance 32, 238-257.

Chowdhury, S. D., Wang, E. Z., 2009. Institutional activism types and CEO compensation: A time-series analysis of large Canadian corporations. Journal of Management 35(1), 5- 
36.

Coles, J. L., Daniel, N. D., Naveen, L., 2006. Managerial incentives and risk-taking. Journal of Financial Economics 79(2), 431-468.

Coles, J., Li, Z., 2016. An empirical assessment of empirical corporate finance. Business Publications 23.

Coles, J., Li, Z., 2018. Managerial attributes, incentives, and performance. Working paper.

Coles, J. L., Li, Z. F., Wang, Y. A., 2018. Industry tournament incentives. The Review of Financial Studies 31(4), 1418-1459.

Conyon, M. J., He, L., 2011. Executive compensation and corporate governance in China. Journal of Corporate Finance 17(4), 1158-1175.

Cornett, M. M., Marcus, A. J., Saunders, A., Tehranian, H., 2007. The impact of institutional ownership on corporate operating performance. Journal of Banking and Finance 31(6), 1771-1794.

Croci, E., Gonenc, H., Ozkan, N., 2012. CEO compensation, family control, and institutional investors in Continental Europe. Journal of Banking and Finance 36(12), 3318-3335.

Cronqvist, H., Fahlenbrach, R., 2008. Large shareholders and corporate policies. The Review of Financial Studies 22(10), 3941-3976.

Cvijanović, D., Dasgupta, A., Zachariadis, K. E., 2016. Ties that bind: How business connections affect mutual fund activism. The Journal of Finance 71(6), 2933-2966.

Dang, C., Li, Z. F., Yang, C., 2018. Measuring firm size in empirical corporate finance. Journal of Banking \& Finance 86, 159-176.

Fan, G., Wang, X., Zhu, H., 2011. NERI index of marketization of China's provinces. National Economic Research Institute, Beijing.

Fan, J. P., Wong, T., Zhang, T., 2013. Institutions and organizational structure: The case of stateowned corporate pyramids. The Journal of Law, Economics, and Organization 29(6), 1217-1252.

Ferreira, M. A., Matos, P., 2008. The colors of investors' money: The role of institutional investors around the world. Journal of Financial Economics 88(3), 499-533.

Ferreira, M. A., Matos, P., Pereira, J. P., Pires, P., 2017. Do locals know better? A comparison of the performance of local and foreign institutional investors. Journal of Banking and Finance 82, 151-164.

Fich, E. M., Harford, J., Tran, A. L., 2015. Motivated monitors: The importance of institutional investors' portfolio weights. Journal of Financial Economics 118(1), 21-48.

Firth, M., Fung, P. M. Y., Rui, O. M., 2007. How ownership and corporate governance influence chief executive pay in China's listed firms. Journal of Business Research 60(7), 776785.

Firth, M., Gao, J., Shen, J., Zhang, Y., 2016. Institutional stock ownership and firms' cash dividend policies: Evidence from China. Journal of Banking and Finance 65, 91-107.

Firth, M., Lin, C., Zou, H., 2010. Friend or foe? The role of state and mutual fund ownership in the split share structure reform in China. The Journal of Financial and Quantitative Analysis, 45(3), 685-706.

Gillan, S. L., Starks, L. T., 2000. Corporate governance proposals and shareholder activism: The role of institutional investors. Journal of Financial Economics 57(2), 275-305.

Golebiowska, A., Urbanek, P., 2016. Corporate boards, large blockholders and executive compensation in banks; Evidence from Poland. Emerging Market Review 28, 203-220.

Harford, J., Li, K., 2007. Decoupling CEO wealth and firm performance: The case of acquiring CEOs. The Journal of Finance 62(2), 917-949.

Hartzell, J. C., Starks, L. T., 2003. Institutional investors and executive compensation. The Journal of Finance 58(6), 2351-2374.

Heckman, J., 1979. Sample section bias as a specification error. Econometrica 47(1), 153-161.

Helwege, J., Intintoli, V. J., Zhang, A., 2012. Voting with their feet or activism? Institutional investors' impact on CEO turnover. Journal of Corporate Finance 18(1), 22-37. 
Huang, W., Zhu, T., 2015. Foreign institutional investors and corporate governance in emerging markets: Evidence of a split-share structure reform in China. Journal of Corporate Finance 32, 312-326.

Jiang, F., Cai, W., Wang, X., Zhu, B., 2018. Multiple large shareholders and corporate investment: Evidence from China. Journal of Corporate Finance 50, 66-83.

Jiang, X., Yuan, Q., 2018. Institutional investors' corporate site visits and corporate innovation. Journal of Corporate Finance 48, 148-168.

Kato, T., Long, C., 2006. Executive compensation, firm performance, and corporate governance in China: Evidence from firms listed in the Shanghai and Shenzhen Stock Exchanges. Economic Development and Cultural Change 54(4), 945-983.

Koh, P.-S., 2007. Institutional investor type, earnings management and benchmark beaters. Journal of Accounting and Public Policy 26(3), 267-299.

Kong, D., Xiang, J., Zhang, J., Lu, Y., 2019. Politically connected independent directors and corporate fraud in China. Accounting and Finance 58(5), 1347-1383.

Laeven, L., Levine, R., 2008. Complex ownership structures and corporate valuations. The Review of Financial Studies 21(2), 579-604.

Li, W., Wu, C., Xu, L., Tang, Q., 2017. Bank connections and the speed of leverage adjustment: evidence from China's listed firms. Accounting and Finance 57(5), 1349-1381.

Li, Z., Patel, S., Ramani, S., 2019. The Role of Mutual Funds in Corporate Social Responsibility. Working Paper.

Lin, C., Ma, Y., Malatesta, P., Xuan, Y., 2011. Ownership structure and the cost of corporate borrowing. Journal of Financial Economics 100(1), 1-23.

Lin, Y., Fu, X., 2017. Does institutional ownership influence firm performance? Evidence from China. International Review of Economics and Finance 49, 17-57.

Liu, N., Bredin, D., Wang, L., Yi, Z., 2014. Domestic and foreign institutional investors' behavior in China. The European Journal of Finance 20(7-9), 728-751.

Luong, H., Moshirian, F., Nguyen, L., Tian, X., Zhang, B., 2017. How Do Foreign Institutional Investors Enhance Firm Innovation? Journal of Financial and Quantitative Analysis, 142.

Maury, B., Pajuste, A., 2005. Multiple large shareholders and firm value. Journal of Banking and Finance 29, 1813-1834.

Mishra, D. R., 2011. Multiple large shareholders and corporate risk taking: Evidence from East Asia. Corporate Governance: An International Review 19(6), 507-528.

Peng, H., Zhang, X., Zhu, X., 2017. Political connections of the board of directors and credit financing: evidence from Chinese private enterprises. Accounting and Finance 57(5), 1481-1516.

Rong, Z., Wu, X., Boeing, P., 2017. The effect of institutional ownership on firm innovation: Evidence from Chinese listed firms. Research Policy 46(9), 1533-1551.

Shen, Y., Gao, D., Bu, D., Yan, L., Chen, P., 2019. CEO hometown ties and tax avoidance evidence from China's listed firms. Accounting and Finance 58(5), 1549-1580.

Shin, J. Y., Seo, J., 2011. Less pay and more sensitivity? Institutional investor heterogeneity and CEO pay. Journal of Management 37(6), 1719-1746.

Shleifer, A., Vishny, R. W., 1997. A survey of corporate governance. The Journal of Finance 52(2), 737-783.

Smith, M. P., 1996. Shareholder activism by institutional investors: Evidence from CalPERS. The Journal of Finance 51(1), 227-252.

Wu, W., Wu, C., Zhou, C., Wu, J., 2012. Political connections, tax benefits and firm performance: Evidence from China. Journal of Accounting and Public Policy 31(3), 277-300.

Yuan, R., Xiao, J. Z., Milonas, N., Zou, J. H., 2009. The role of financial institutions in the corporate governance of listed Chinese companies. British Journal of Management 20(4), 562-580. 
Yuan, R., Xiao, J. Z., Zou, H., 2008. Mutual funds' ownership and firm performance: Evidence from China. Journal of Banking and Finance 32(8), 1552-1565.

Zhu, Y., Wu, Z., Zhang, H., Yu, J., 2017. Media sentiment, institutional investors and probability of stock price crash: evidence from Chinese stock markets. Accounting and Finance 57(5), 1635-1670.

Zou, L., Tang, T., Li, X., 2016. The stock preferences of domestic versus foreign investors: Evidence from Qualified Foreign Institutional Investors (QFIIs) in China. Journal of Multinational Financial Management 37, 12-28. 
Table 1. Summary statistics

\begin{tabular}{|c|c|c|c|c|c|c|c|c|}
\hline Variable & Observations & Mean & Std.Dev. & Median & Min & $25 \%$ & $75 \%$ & Max \\
\hline \multicolumn{9}{|c|}{ Panel A: Executive characteristics } \\
\hline CEO pay & 15,613 & 480,899 & 299,482 & 403,000 & 120,000 & 233,454 & 680,000 & $1,056,000$ \\
\hline CEO age & 15,613 & 47.825 & 5.205 & 48 & 40 & 43 & 52 & 56 \\
\hline \multicolumn{9}{|c|}{ Panel B: Institutional ownership } \\
\hline Mutual $^{*}(\%)$ & 9,501 & 4.189 & 4.468 & 2.52 & 0.02 & 0.88 & 6.06 & 33.416 \\
\hline QFII* $(\%)$ & 1,548 & 1.254 & 1.263 & 0.88 & 0.01 & 0.44 & 1.63 & 12.468 \\
\hline Others ${ }^{*}(\%)$ & 10,228 & 2.87 & 4.076 & 1.68 & 0.025 & 0.71 & 3.56 & 73.03 \\
\hline Mutualratio* (\%) & 9,501 & 14.389 & 20.028 & 7.183 & 0.035 & 2.443 & 18.187 & 330.198 \\
\hline QFIIratio* (\%) & 1,548 & 4.101 & 5.598 & 2.394 & 0.012 & 1.068 & 4.968 & 68.430 \\
\hline Mutuald & 15,613 & 0.627 & 0.484 & 1 & 0 & 0 & 1 & 1 \\
\hline QFIId & 15,613 & 0.099 & 0.299 & 0 & 0 & 0 & 0 & 1 \\
\hline \multicolumn{9}{|c|}{ Panel C: Firm characteristics and corporate governance } \\
\hline Board Size & 15,613 & 9.057 & 1.828 & 9 & 3 & 8 & 9 & 19 \\
\hline Independent & 15,613 & 3.274 & 0.664 & 3 & 1 & 3 & 4 & 8 \\
\hline Leverage $(\%)$ & 15,613 & 48.068 & 20.200 & 48.927 & 5.660 & 32.946 & 63.288 & 99.861 \\
\hline Firm Size (million) & 15,613 & 4,890 & 4,840 & 2,810 & 720 & 1,360 & 6,560 & 15,700 \\
\hline Largest (\%) & 15,613 & 36.602 & 15.503 & 34.655 & 2.197 & 24.210 & 47.890 & 89.990 \\
\hline $\mathrm{Q}$ & 15,613 & 1.750 & 0.834 & 1.454 & 0.893 & 1.060 & 2.251 & 3.393 \\
\hline \multicolumn{9}{|c|}{ Panel D: Firm performance } \\
\hline ROA (\%) & 15,613 & 3.626 & 5.681 & 3.300 & -27.920 & 1.220 & 6.190 & 20.460 \\
\hline RET $(\%)$ & 15,613 & 41.591 & 92.095 & 15.03 & -86.930 & -11.49 & 70.59 & 142.87 \\
\hline \multicolumn{9}{|c|}{ Panel E: Firm type distributions } \\
\hline & \multicolumn{3}{|c|}{ SOEs } & \multicolumn{5}{|c|}{ Non-SOEs } \\
\hline $\begin{array}{l}\text { Observations } \\
\text { (percentage) }\end{array}$ & \multicolumn{3}{|c|}{$8,922(57.145 \%)$} & \multicolumn{5}{|c|}{$6,691(42.855 \%)$} \\
\hline \multicolumn{9}{|c|}{$\begin{array}{l}\text { Descriptive statistics of observations from } 2005 \text { to } 2015 \text {, excluding observations with leverage larger than } 1 \text {. Panel } \\
\text { A reports summary statistics for executive characteristics. CEO pay is the cash compensation of CEO, which has } \\
\text { been available since } 2005 \text {. Panel B reports summary statistics of firm institutional ownership. * represents the } \\
\text { summary result of firms with positive institutional ownership. Specifically, Mutual }{ }^{*} \text { represents firms which have } \\
\text { mutual funds as shareholders. QFII* represents firms which have QFIIs as shareholders. Others }{ }^{*} \text { represents firms } \\
\text { which have other types of institutional investors as shareholders. Panel C reports summary statistics for firm } \\
\text { characteristics and corporate governance. Panel D reports summary statistics for firm performance. Panel E reports } \\
\text { firm distribution. All the definitions of the variables are listed in Appendix A and the value of variables are in } \\
\text { terms of China's currency, the RMB. }\end{array}$} \\
\hline
\end{tabular}


Table 2. Effects of institutional ownership on the CEO pay-performance relationship

\begin{tabular}{|c|c|c|c|}
\hline \multicolumn{4}{|c|}{ Dependent variable: the natural log of CEO pay } \\
\hline & (1) & (2) & (3) \\
\hline Mutuald & $\begin{array}{l}0.012 \\
(1.06)\end{array}$ & & \\
\hline QFIId & $\begin{array}{l}-0.007 \\
(-0.36)\end{array}$ & & \\
\hline Mutuald*ROA & $\begin{array}{c}0.686 * * * \\
(3.87)\end{array}$ & & \\
\hline QFIId*ROA & $\begin{array}{l}0.025 \\
(0.10)\end{array}$ & & \\
\hline Mutual & & $\begin{array}{l}0.310 \\
(1.63)\end{array}$ & \\
\hline QFII & & $\begin{array}{l}-0.303 \\
(-0.24)\end{array}$ & \\
\hline Mutual*ROA & & $\begin{array}{c}8.454 * * * \\
(3.75)\end{array}$ & \\
\hline QFII*ROA & & $\begin{array}{l}7.777 \\
(0.42)\end{array}$ & \\
\hline Mutualratio & & & $\begin{array}{l}0.061 \\
(1.37)\end{array}$ \\
\hline QFIIratio & & & $\begin{array}{l}-0.012 \\
(-0.05)\end{array}$ \\
\hline Mutualratio*ROA & & & $\begin{array}{c}1.556^{* * * *} \\
(3.38)\end{array}$ \\
\hline QFIIratio*ROA & & & $\begin{array}{l}0.024 \\
(0.01)\end{array}$ \\
\hline ROA & $\begin{array}{c}0.857 * * * \\
(6.10)\end{array}$ & $\begin{array}{c}0.970 * * * \\
(7.83)\end{array}$ & $\begin{array}{c}1.047^{* * * *} \\
(8.63)\end{array}$ \\
\hline Others & $\begin{array}{l}0.110 \\
(0.69)\end{array}$ & $\begin{array}{l}0.149 \\
(0.92)\end{array}$ & $\begin{array}{l}0.139 \\
(0.86)\end{array}$ \\
\hline Size & $\begin{array}{c}0.177 * * * \\
(9.60)\end{array}$ & $\begin{array}{c}0.186^{* * *} \\
(10.17)\end{array}$ & $\begin{array}{c}0.184^{* * * *} \\
(10.08)\end{array}$ \\
\hline Leverage & $\begin{array}{c}-0.139 * * \\
(-2.57)\end{array}$ & $\begin{array}{c}-0.149 * * * \\
(-2.78)\end{array}$ & $\begin{array}{c}-0.148 * * * \\
(-2.75)\end{array}$ \\
\hline Board & $\begin{array}{c}0.139 * * \\
(2.48)\end{array}$ & $\begin{array}{c}0.141^{* *} \\
(2.52)\end{array}$ & $\begin{array}{c}0.137 * * \\
(2.45)\end{array}$ \\
\hline Independent & $\begin{array}{l}0.074 \\
(0.52)\end{array}$ & $\begin{array}{l}0.080 \\
(0.57)\end{array}$ & $\begin{array}{l}0.074 \\
(0.52)\end{array}$ \\
\hline Largest & $\begin{array}{l}-0.069 \\
(-0.71)\end{array}$ & $\begin{array}{l}-0.062 \\
(-0.64)\end{array}$ & $\begin{array}{l}-0.037 \\
(-0.38)\end{array}$ \\
\hline CEOage & $\begin{array}{c}0.007 * * * \\
(4.16)\end{array}$ & $\begin{array}{c}0.007 * * * \\
(4.21)\end{array}$ & $\begin{array}{c}0.007 * * * \\
(4.19)\end{array}$ \\
\hline Year fixed effects & Yes & Yes & Yes \\
\hline Firm fixed effects & Yes & Yes & Yes \\
\hline Observations & 13,028 & 13,028 & 13,028 \\
\hline R-squared & 0.344 & 0.346 & 0.345 \\
\hline
\end{tabular}

This table reports the effects of institutional investors on the CEO pay-performance relationship using the firm fixed-effect model. Dependent variable is the natural log of CEO compensation. Mutuald (QFIId) is the dummy variable, which is equal to 1 if there are mutual funds (QFIIs) as shareholders in a firm and 0 otherwise. Mutual and QFII denote ownership level of mutual funds and QFIIs, respectively. Mutualratio and QFIIratio are the ratios of mutual funds' ownership and QFIIs' ownership to the controlling shareholder's ownership, respectively. Others represents the sum of ownership of other types of institutional investors. Size is the natural log of firms' total assets. Leverage is the ratio of total debt to total assets. Board is the natural log of firms' numbers of directors on the board. Independent is the proportion of independent directors on the board. Largest is the largest shareholders' ownership. CEOage is the age of CEO. Year dummies are included. The t-statistics (in parentheses) are computed using robust standard errors clustered at the firm level. *, ${ }^{* *}$ and $* * *$ indicate significance at the $10 \%, 5 \%$ and $1 \%$ levels, respectively. 
Table 3. Effects of institutional ownership on the CEO pay-performance relationship in SOEs and nonSOEs

\begin{tabular}{|c|c|c|c|c|c|c|}
\hline \multicolumn{7}{|c|}{ Dependent variable: the natural log of CEO pay } \\
\hline & \multicolumn{3}{|c|}{ SOE subsample } & \multicolumn{3}{|c|}{ Non-SOE subsample } \\
\hline & $(1)$ & $(2)$ & (3) & $(4)$ & $(5)$ & $(6)$ \\
\hline \multirow[t]{2}{*}{ Mutuald } & $0.032 * *$ & & & -0.021 & & \\
\hline & $(2.24)$ & & & $(-1.13)$ & & \\
\hline \multirow[t]{2}{*}{ QFIId } & 0.003 & & & -0.030 & & \\
\hline & $(0.12)$ & & & $(-0.76)$ & & \\
\hline \multirow[t]{2}{*}{ Mutuald*ROA } & $0.533 * *$ & & & $0.944 * * *$ & & \\
\hline & $(2.17)$ & & & $(3.60)$ & & \\
\hline \multirow[t]{2}{*}{ QFIId*ROA } & 0.028 & & & 0.053 & & \\
\hline & $(0.08)$ & & & $(0.11)$ & & \\
\hline \multirow[t]{2}{*}{ Mutual } & & $0.641 * * *$ & & & -0.350 & \\
\hline & & $(2.69)$ & & & $(-1.21)$ & \\
\hline \multirow[t]{2}{*}{ QFII } & & 0.301 & & & -1.558 & \\
\hline & & $(0.22)$ & & & $(-0.62)$ & \\
\hline \multirow[t]{2}{*}{ Mutual*ROA } & & $7.481 * *$ & & & $11.926 * * *$ & \\
\hline & & $(2.40)$ & & & (3.92) & \\
\hline \multirow[t]{2}{*}{ QFII*ROA } & & 4.434 & & & 17.361 & \\
\hline & & $(0.20)$ & & & $(0.56)$ & \\
\hline \multirow[t]{2}{*}{ Mutualratio } & & & $0.139 * *$ & & & -0.067 \\
\hline & & & $(2.08)$ & & & $(-1.15)$ \\
\hline \multirow[t]{2}{*}{ QFIIratio } & & & -0.027 & & & -0.044 \\
\hline & & & $(-0.09)$ & & & $(-0.09)$ \\
\hline \multirow[t]{2}{*}{ Mutualratio*ROA } & & & $1.405^{*}$ & & & $2.292 * * *$ \\
\hline & & & $(1.81)$ & & & $(4.32)$ \\
\hline \multirow[t]{2}{*}{ QFIIratio*ROA } & & & 1.656 & & & 0.107 \\
\hline & & & $(0.30)$ & & & $(0.02)$ \\
\hline \multirow[t]{2}{*}{ ROA } & $1.194 * * *$ & $1.257 * * *$ & $1.335 * * *$ & 0.320 & $0.463 * *$ & $0.545^{* * *}$ \\
\hline & $(6.61)$ & (7.93) & $(8.52)$ & $(1.46)$ & $(2.38)$ & $(2.85)$ \\
\hline Control & Yes & Yes & Yes & Yes & Yes & Yes \\
\hline Year fixed effects & Yes & Yes & Yes & Yes & Yes & Yes \\
\hline Firm fixed effects & Yes & Yes & Yes & Yes & Yes & Yes \\
\hline Observations & 7,588 & 7,588 & 7,588 & 5,440 & 5,440 & 5,440 \\
\hline \multirow[t]{2}{*}{ R-squared } & 0.356 & 0.359 & 0.357 & 0.332 & 0.333 & 0.333 \\
\hline & (1) vs (4) & (2) vs (5) & (3) vs (6) & & & \\
\hline Chow test & $5.205 * * *$ & $5.327 * * *$ & $5.293 * * *$ & & & \\
\hline
\end{tabular}

This table shows different effects of institutional investors in SOEs and non-SOEs using firm fixed-effect model. Dependent variable is the natural log of CEO compensation. Columns (1) to (3) are results of using SOEs as the sample and columns (4) to (6) are results of using non-SOEs as the sample. Mutuald (QFIId) is the dummy variable, which is equal to 1 if there are mutual funds (QFIIs) as shareholders in a firm and 0 otherwise. Mutual and QFII denotes ownership level of mutual funds and QFIIs, respectively. Mutualratio and QFIIratio are the ratios of mutual funds' ownership and QFIIs' ownership to the controlling shareholder's ownership, respectively. Control variables in equation (1) are included in each regression. Definitions of all the variables are the same as those in previous tables. Year dummies are included. The Chow tests' $\mathrm{F}$ statistics reveal the significance of the difference in the coefficients on Mutuald*ROA, Mutual ${ }^{*} R O A$ and Mutualratio*ROA for SOEs and non-SOEs. The t-statistics (in parentheses) are computed using robust standard errors clustered at the firm level. *, ** and *** indicate significance at the $10 \%, 5 \%$ and $1 \%$ levels, respectively. 
Table 4. Effects of institutional ownership on the CEO pay-performance relationship in central government controlled SOEs and local government controlled SOEs

\begin{tabular}{|c|c|c|c|c|c|c|}
\hline Dependent variable & \multicolumn{3}{|c|}{$\begin{array}{c}\text { Central government controlled SOEs } \\
\text { subsample }\end{array}$} & \multicolumn{3}{|c|}{$\begin{array}{l}\text { Local government controlled SOEs } \\
\text { subsample }\end{array}$} \\
\hline & $(1)$ & $(2)$ & (3) & (4) & $(5)$ & (6) \\
\hline Mutuald & $\begin{array}{c}0.056 * * \\
(2.03)\end{array}$ & & & $\begin{array}{l}0.022 \\
(1.34)\end{array}$ & & \\
\hline QFIId & $\begin{array}{l}-0.038 \\
(-0.80)\end{array}$ & & & $\begin{array}{l}0.024 \\
(0.87)\end{array}$ & & \\
\hline Mutuald*ROA & $\begin{array}{l}-0.123 \\
(-0.29)\end{array}$ & & & $\begin{array}{l}0.785^{* * *} \\
(2.69)\end{array}$ & & \\
\hline QFIId*ROA & $\begin{array}{l}0.233 \\
(0.39)\end{array}$ & & & $\begin{array}{l}-0.112 \\
(-0.27)\end{array}$ & & \\
\hline Mutual & & $\begin{array}{l}0.577 \\
(1.33)\end{array}$ & & & $\begin{array}{c}0.679 * * \\
(2.37)\end{array}$ & \\
\hline QFII & & $\begin{array}{l}-3.107 \\
(-1.07)\end{array}$ & & & $\begin{array}{l}1.590 \\
(1.04)\end{array}$ & \\
\hline Mutual*ROA & & $\begin{array}{l}4.944 \\
(0.78)\end{array}$ & & & $\begin{array}{c}8.396^{* *} \\
(2.30)\end{array}$ & \\
\hline QFII*ROA & & $\begin{array}{c}38.960 \\
(0.85)\end{array}$ & & & $\begin{array}{l}-7.371 \\
(-0.29)\end{array}$ & \\
\hline Mutualratio & & & $\begin{array}{l}0.200^{*} \\
(1.80)\end{array}$ & & & $\begin{array}{l}0.125 \\
(1.60)\end{array}$ \\
\hline QFIIratio & & & $\begin{array}{c}-1.077 * \\
(-1.73)\end{array}$ & & & $\begin{array}{l}0.351 \\
(1.08)\end{array}$ \\
\hline Mutualratio*ROA & & & $\begin{array}{l}0.078 \\
(0.05)\end{array}$ & & & $\begin{array}{c}1.821 * * \\
(2.07)\end{array}$ \\
\hline QFIIratio*ROA & & & $\begin{array}{l}12.025 \\
(0.86)\end{array}$ & & & $\begin{array}{l}-1.923 \\
(-0.31)\end{array}$ \\
\hline ROA & $\begin{array}{l}1.406 * * * \\
(3.93)\end{array}$ & $\begin{array}{c}1.198 * * * \\
(3.68)\end{array}$ & $\begin{array}{l}1.316^{* * *} \\
(4.13)\end{array}$ & $\begin{array}{l}1.130 * * * \\
(5.53)\end{array}$ & $\begin{array}{l}1.250 * * * \\
(6.89)\end{array}$ & $\begin{array}{l}1.323 * * * \\
(7.35)\end{array}$ \\
\hline Control & Yes & Yes & Yes & Yes & Yes & Yes \\
\hline Year fixed effects & Yes & Yes & Yes & Yes & Yes & Yes \\
\hline Firm fixed effects & Yes & Yes & Yes & Yes & Yes & Yes \\
\hline Observations & 2,122 & 2,122 & 2,122 & 5,466 & 5,466 & 5,466 \\
\hline R-squared & 0.303 & 0.308 & 0.306 & 0.327 & 0.330 & 0.329 \\
\hline
\end{tabular}

This table shows different effects of institutional investors in central government controlled SOEs and local government controlled SOEs using firm fixed-effect model. Dependent variable is the natural log of CEO compensation. Columns (1) to (3) are results of using central government controlled SOEs as the sample and columns (4) to (6) are results of using local government controlled SOEs as the sample. Mutuald (QFIId) is the dummy variable, which is equal to 1 if there are mutual funds (QFIIs) as shareholders in a firm and 0 otherwise. Mutual and QFII denotes ownership level of mutual funds and QFIIs, respectively. Mutualratio and QFIIratio are the ratios of mutual funds' ownership and QFIIs' ownership to the controlling shareholder's ownership, respectively. Control variables in equation (1) are included in each regression. Definitions of all the variables are the same as those in previous tables. Year dummies are included. The t-statistics (in parentheses) are computed using robust standard errors clustered at the firm level. * $* *$ and $* * *$ indicate significance at the $10 \%, 5 \%$ and $1 \%$ levels, respectively. 
Table 5. Effects of institutional ownership on the CEO pay-performance (Heckman and PSM)

\begin{tabular}{|c|c|c|c|c|c|c|}
\hline \multicolumn{7}{|c|}{ Dependent variable: the natural log of CEO pay } \\
\hline & \multicolumn{3}{|c|}{ Heckman two-stage (second stage) } & \multicolumn{3}{|c|}{ PSM matching method } \\
\hline & (1) & $(2)$ & (3) & (4) & (5) & (6) \\
\hline Mutuald & $\begin{array}{l}-0.023 \\
(-118)\end{array}$ & & & $\begin{array}{l}0.010 \\
(0.78)\end{array}$ & & \\
\hline QFIId & $\begin{array}{l}0.010 \\
(0.40)\end{array}$ & & & $\begin{array}{l}-0.006 \\
(-0.28)\end{array}$ & & \\
\hline Mutuald*ROA & $\begin{array}{c}0.705 * * * \\
(3.96)\end{array}$ & & & $\begin{array}{c}0.548 * * * \\
(2.72)\end{array}$ & & \\
\hline QFIId*ROA & $\begin{array}{l}0.043 \\
(0.16)\end{array}$ & & & $\begin{array}{l}-0.038 \\
(-0.14)\end{array}$ & & \\
\hline Mutual & & $\begin{array}{l}0.168 \\
(0.82)\end{array}$ & & & $\begin{array}{l}0.354^{*} \\
(1.77)\end{array}$ & \\
\hline QFII & & $\begin{array}{l}1.245 \\
(0.81)\end{array}$ & & & $\begin{array}{l}-0.161 \\
(-0.13)\end{array}$ & \\
\hline Mutual*ROA & & $\begin{array}{c}8.918 * * * \\
(3.96)\end{array}$ & & & $\begin{array}{c}7.400 * * * \\
(3.18)\end{array}$ & \\
\hline QFII*ROA & & $\begin{array}{l}7.352 \\
(0.40)\end{array}$ & & & $\begin{array}{l}4.463 \\
(0.24)\end{array}$ & \\
\hline Mutualratio & & & $\begin{array}{l}0.021 \\
(0.45)\end{array}$ & & & $\begin{array}{l}0.067 \\
(1.42)\end{array}$ \\
\hline QFIIratio & & & $\begin{array}{l}0.171 \\
(0.58)\end{array}$ & & & $\begin{array}{l}0.027 \\
(0.10)\end{array}$ \\
\hline Mutualratio*ROA & & & $\begin{array}{c}1.686^{* * *} \\
(3.72)\end{array}$ & & & $\begin{array}{c}1.333^{* * *} * \\
(2.84)\end{array}$ \\
\hline QFIIratio*ROA & & & $\begin{array}{l}0.270 \\
(0.06)\end{array}$ & & & $\begin{array}{l}-1.048 \\
(-0.25)\end{array}$ \\
\hline ROA & $\begin{array}{c}0.839 * * * \\
(5.97)\end{array}$ & $\begin{array}{c}0.954 * * * \\
(7.67)\end{array}$ & $\begin{array}{c}1.024 * * * \\
(8.42)\end{array}$ & $\begin{array}{c}1.125^{* * * *} \\
(6.14)\end{array}$ & $\begin{array}{c}1.215^{* * *} \\
(8.12)\end{array}$ & $\begin{array}{c}1.312 * * * \\
(9.08)\end{array}$ \\
\hline Lambda $_{\text {Mutual }}$ & $\begin{array}{c}-1.818 * * \\
(-2.04)\end{array}$ & $\begin{array}{c}-0.900^{*} \\
(-1.78)\end{array}$ & $\begin{array}{c}-1.242 * * \\
(-2.54)\end{array}$ & & & \\
\hline Lambda $_{Q F I}$ & $\begin{array}{l}2.625 \\
(1.12)\end{array}$ & $\begin{array}{l}3.958^{*} \\
(1.76)\end{array}$ & $\begin{array}{l}2.411 \\
(1.15)\end{array}$ & & & \\
\hline Control & Yes & Yes & Yes & Yes & Yes & Yes \\
\hline Year fixed effects & Yes & Yes & Yes & Yes & Yes & Yes \\
\hline Firm fixed effects & Yes & Yes & Yes & Yes & Yes & Yes \\
\hline Observations & 13,028 & 13,028 & 13,028 & 11,206 & 11,206 & 11,206 \\
\hline R-squared & 0.298 & 0.302 & 0.301 & 0.331 & 0.334 & 0.332 \\
\hline
\end{tabular}

This table shows the effects of institutional investors on the CEO pay-performance relationship using Heckman two-stage method and PSM. Specifically, columns (1) to (3) are results of using Heckman two-stage method (second stage), and columns (4) to (6) are results of using PSM. Control variables in equation (1) are included in each regression. Lambda $a_{\text {Mutual }}$ and $L a m b d a_{Q F I}$ are inverse mills ratios obtained from the first stage of Heckman two-stage model. Definitions of all the variables are the same as those in previous tables. The t-statistics (in parentheses) are computed using robust standard errors clustered at the firm level. *,** and *** indicate significance at the $10 \%, 5 \%$ and $1 \%$ levels, respectively. 
Table 6. Effects of institutional investors in firms with larger and smaller industry tournament

\begin{tabular}{|c|c|c|c|c|c|c|}
\hline \multicolumn{7}{|c|}{ Dependent variable: the natural log of CEO pay } \\
\hline & \multicolumn{3}{|c|}{ Firms with larger industry tournament } & \multicolumn{3}{|c|}{ Firms with smaller industry tournament } \\
\hline & $(1)$ & & & & $(5)$ & \\
\hline \multirow[t]{2}{*}{ Mutuald } & 0.001 & & & 0.010 & & \\
\hline & $(0.07)$ & & & $(1.05)$ & & \\
\hline \multirow[t]{2}{*}{ QFIId } & -0.016 & & & 0.007 & & \\
\hline & $(-0.73)$ & & & $(0.48)$ & & \\
\hline \multirow[t]{2}{*}{ Mutuald*ROA } & 0.343 & & & $0.410 * *$ & & \\
\hline & $(1.80)$ & & & $(2.59)$ & & \\
\hline \multirow[t]{2}{*}{ QFIId*ROA } & -0.087 & & & 0.064 & & \\
\hline & $(-0.34)$ & & & $(0.31)$ & & \\
\hline \multirow[t]{2}{*}{ Mutual } & & 0.025 & & & $0.345^{* *}$ & \\
\hline & & $(0.12)$ & & & $(2.03)$ & \\
\hline \multirow[t]{2}{*}{ QFII } & & -0.278 & & & 0.484 & \\
\hline & & $(-0.15)$ & & & $(0.57)$ & \\
\hline \multirow[t]{2}{*}{ Mutual*ROA } & & 3.292 & & & $4.486^{* *}$ & \\
\hline & & $(1.34)$ & & & $(2.16)$ & \\
\hline \multirow{2}{*}{ QFII*ROA } & & 2.488 & & & 1.026 & \\
\hline & & $(0.08)$ & & & $(0.08)$ & \\
\hline \multirow[t]{2}{*}{ Mutualratio } & & & -0.001 & & & 0.063 \\
\hline & & & $(-0.01)$ & & & $(1.48)$ \\
\hline \multirow[t]{2}{*}{ QFIIratio } & & & -0.381 & & & 0.054 \\
\hline & & & $(-0.82)$ & & & $(0.29)$ \\
\hline \multirow[t]{2}{*}{ Mutualratio*ROA } & & & 0.782 & & & $0.771 *$ \\
\hline & & & $(1.37)$ & & & $(1.86)$ \\
\hline \multirow[t]{2}{*}{ QFIIratio*ROA } & & & 1.488 & & & -0.108 \\
\hline & & & $(0.23)$ & & & $(-0.03)$ \\
\hline \multirow[t]{2}{*}{ ROA } & 0.026 & 0.082 & 0.088 & $0.813 * * *$ & $0.912 * * *$ & $0.970 * * *$ \\
\hline & $(0.23)$ & $(0.80)$ & $(0.87)$ & $(5.73)$ & $(7.70)$ & $(8.46)$ \\
\hline Control & Yes & Yes & Yes & Yes & Yes & Yes \\
\hline Year fixed effects & Yes & Yes & Yes & Yes & Yes & Yes \\
\hline Firm fixed effects & Yes & Yes & Yes & Yes & Yes & Yes \\
\hline Observations & 3,543 & 3,543 & 3,543 & 9,485 & 9,485 & 9,485 \\
\hline R-squared & 0.039 & 0.040 & 0.040 & 0.204 & 0.209 & 0.207 \\
\hline
\end{tabular}

This table shows the effects of institutional investors on pay-performance relationship in firms with larger or smaller industry tournament using firm fixed-effect model. Columns (1) to (3) are results of testing firms with larger industry tournament. Columns (4) to (6) are results of testing firms with smaller industry tournament. Control variables in equation (1) are included in each regression. Definitions of all the variables are the same as those in previous tables. Year dummies are included. The t-statistics (in parentheses) are computed using robust standard errors clustered at the firm level. *,** and *** indicate significance at the $10 \%, 5 \%$ and $1 \%$ levels, respectively. 
Table 7. Effects of institutional investors on the CEO pay-performance relationship across regions

\begin{tabular}{|c|c|c|c|c|c|c|}
\hline \multicolumn{7}{|c|}{ Dependent variable: the natural log of CEO pay } \\
\hline & $(1)$ & $(2)$ & (3) & (4) & $(5)$ & $(6)$ \\
\hline Mutuald & 0.013 & & & 0.021 & & \\
\hline QFIId & $\begin{array}{l}(0.93) \\
0.001 \\
(0.05)\end{array}$ & & & $\begin{array}{l}(0.98) \\
-0.002 \\
(-0.04)\end{array}$ & & \\
\hline Mutuald*ROA & $\begin{array}{c}0.725 * * * \\
(3.50)\end{array}$ & & & $\begin{array}{l}0.626 \\
(1.59)\end{array}$ & & \\
\hline QFIId*ROA & $\begin{array}{l}-0.088 \\
(-0.27)\end{array}$ & & & $\begin{array}{l}0.235 \\
(0.42)\end{array}$ & & \\
\hline Mutual & & $\begin{array}{l}0.329 \\
(1.37)\end{array}$ & & & $\begin{array}{l}0.165 \\
(0.46)\end{array}$ & \\
\hline QFII & & $\begin{array}{l}0.011 \\
(0.01)\end{array}$ & & & $\begin{array}{l}-0.951 \\
(-0.46)\end{array}$ & \\
\hline Mutual*ROA & & $\begin{array}{c}9.314 * * * \\
(3.46)\end{array}$ & & & $\begin{array}{l}5.033 \\
(1.08)\end{array}$ & \\
\hline QFII*ROA & & $\begin{array}{l}2.594 \\
(0.11)\end{array}$ & & & $\begin{array}{r}23.197 \\
(0.61)\end{array}$ & \\
\hline Mutualratio & & & $\begin{array}{l}0.068 \\
(1.17)\end{array}$ & & & $\begin{array}{l}0.032 \\
(0.40)\end{array}$ \\
\hline QFIIratio & & & $\begin{array}{l}0.141 \\
(0.48)\end{array}$ & & & $\begin{array}{l}-0.717 \\
(-1.13)\end{array}$ \\
\hline Mutualratio*ROA & & & $\begin{array}{c}1.701 * * * \\
(2.99)\end{array}$ & & & $\begin{array}{l}0.588 \\
(0.60)\end{array}$ \\
\hline QFIIratio*ROA & & & $\begin{array}{l}-0.951 \\
(-0.19)\end{array}$ & & & $\begin{array}{l}-1.920 \\
(-0.20)\end{array}$ \\
\hline ROA & $\begin{array}{c}0.782 * * * \\
(4.61)\end{array}$ & $\begin{array}{c}0.907 * * * \\
(5.90)\end{array}$ & $\begin{array}{c}0.987 * * * \\
(6.57)\end{array}$ & $\begin{array}{c}1.000 * * * \\
(3.73)\end{array}$ & $\begin{array}{c}1.161 * * * \\
(4.87)\end{array}$ & $\begin{array}{c}1.267 * * * \\
(5.37)\end{array}$ \\
\hline Control & Yes & Yes & Yes & Yes & Yes & Yes \\
\hline Year fixed effects & Yes & Yes & Yes & Yes & Yes & Yes \\
\hline Firm fixed effects & Yes & Yes & Yes & Yes & Yes & Yes \\
\hline Observations & 9,062 & 9,062 & 9,062 & 2,697 & 2,697 & 2,697 \\
\hline R-squared & 0.327 & 0.329 & 0.328 & 0.397 & 0.396 & 0.395 \\
\hline
\end{tabular}

This table shows the effects of institutional investors across regions using firm fixed-effect model. Columns (1) to (3) are results using firms from more developed regions as the sample and columns (4) to (6) are results using firms from less developed regions as the sample. The slightly lower number of observations is due to missing information about some firms' locations. Dependent variable is the natural log of CEO compensation. Mutuald (QFIId) is the dummy variable, which is equal to 1 if there are mutual funds (QFIIs) as shareholders in a firm and 0 otherwise. Mutual and QFII denotes ownership level of mutual funds and QFIIs, respectively. Mutualratio and QFIIratio are the ratios of mutual funds' ownership and QFIIs' ownership to the controlling shareholder's ownership, respectively. Control variables in equation (1) are included in each regression. Definitions of all the variable are the same as those in previous tables. Year dummies are included. The t-statistics (in parentheses) are computed using robust standard errors clustered at the firm level. *, ** and *** indicate significance at the $10 \%$, $5 \%$ and $1 \%$ levels, respectively. 
Table 8. Effects of institutional ownership on the CEO pay-performance relationship using alternative definition of CEO pay

\begin{tabular}{|c|c|c|c|c|c|c|}
\hline \multirow[t]{2}{*}{ Dependent variable } & \multicolumn{3}{|c|}{$\begin{array}{c}\text { The natural log of (CEO pay + value } \\
\text { of CEO's shareholding) }\end{array}$} & \multicolumn{3}{|c|}{$\begin{array}{l}\text { The natural log of average compensation of } \\
\text { the top three executives }\end{array}$} \\
\hline & (1) & (2) & (3) & (4) & $(5)$ & (6) \\
\hline Mutuald & $\begin{array}{l}0.004 \\
(0.16)\end{array}$ & & & $\begin{array}{c}0.028^{* *} \\
(2.34)\end{array}$ & & \\
\hline QFIId & $\begin{array}{l}0.013 \\
(0.41)\end{array}$ & & & $\begin{array}{l}0.003 \\
(0.14)\end{array}$ & & \\
\hline Mutuald*ROA & $\begin{array}{c}1.129 * * * \\
(3.52)\end{array}$ & & & $\begin{array}{c}0.398^{* *} \\
(2.10)\end{array}$ & & \\
\hline QFIId*ROA & $\begin{array}{l}-0.648 \\
(-1.40)\end{array}$ & & & $\begin{array}{l}-0.099 \\
(-0.37)\end{array}$ & & \\
\hline Mutual & & $\begin{array}{c}0.789 * * \\
(2.16)\end{array}$ & & & $\begin{array}{c}0.478 * * \\
(2.18)\end{array}$ & \\
\hline QFII & & $\begin{array}{l}-0.163 \\
(-0.07)\end{array}$ & & & $\begin{array}{l}0.849 \\
(0.72)\end{array}$ & \\
\hline Mutual*ROA & & $\begin{array}{c}8.978 * * \\
(2.05)\end{array}$ & & & $\begin{array}{c}5.813^{* *} \\
(2.06)\end{array}$ & \\
\hline QFII*ROA & & $\begin{array}{c}-36.944 \\
(-1.11)\end{array}$ & & & $\begin{array}{l}4.896 \\
(0.29)\end{array}$ & \\
\hline Mutualratio & & & $\begin{array}{c}0.175 * * \\
(2.09)\end{array}$ & & & $\begin{array}{l}0.068 \\
(1.26)\end{array}$ \\
\hline QFIIratio & & & $\begin{array}{l}-0.007 \\
(-0.01)\end{array}$ & & & $\begin{array}{l}0.130 \\
(0.48)\end{array}$ \\
\hline Mutualratio*ROA & & & $\begin{array}{l}1.635^{*} \\
(1.66)\end{array}$ & & & $\begin{array}{c}1.206^{* *} \\
(2.10)\end{array}$ \\
\hline QFIIratio*ROA & & & $\begin{array}{c}-10.319 \\
(-1.35)\end{array}$ & & & $\begin{array}{l}1.814 \\
(0.40)\end{array}$ \\
\hline ROA & $\begin{array}{c}1.035^{* * *} \\
(4.82)\end{array}$ & $\begin{array}{c}1.306 * * * \\
(6.58)\end{array}$ & $\begin{array}{c}1.379 * * * \\
(7.12)\end{array}$ & $\begin{array}{c}1.038^{* * * *} \\
(6.93)\end{array}$ & $\begin{array}{c}1.064 * * * \\
(8.18)\end{array}$ & $\begin{array}{c}1.114 * * * \\
(8.73)\end{array}$ \\
\hline Control & Yes & Yes & Yes & Yes & Yes & Yes \\
\hline Year fixed effects & Yes & Yes & Yes & Yes & Yes & Yes \\
\hline Firm fixed effects & Yes & Yes & Yes & Yes & Yes & Yes \\
\hline Observations & 13,028 & 13,028 & 13,028 & 13,028 & 13,028 & 13,028 \\
\hline R-squared & 0.174 & 0.176 & 0.175 & 0.508 & 0.510 & 0.509 \\
\hline
\end{tabular}

This table shows the results using different measurement of CEO payment. Specifically, columns (1) to (3) use the natural log of (CEO pay + value of CEO's shareholding) as the measurement of CEO compensation. Columns (4) to (6) use the natural log of average payment of the top three executives as the measurement of CEO payment. Control variables in equation (1) are included in each regression. Control variables in equation (1) are included in each regression. Definitions of all the variables are the same as those in previous tables. Year dummies are included. The t-statistics (in parentheses) are computed using robust standard error clustered at the firm level. *, $* *$ and $* * *$ indicate significance at the $10 \%, 5 \%$ and $1 \%$ levels, respectively. 


\begin{tabular}{|c|c|}
\hline Variables & Definition \\
\hline \multicolumn{2}{|c|}{ Panel A: Executive compensation and age } \\
\hline CEO pay & The natural log of CEO compensation \\
\hline CEO age & The age of CEO \\
\hline \multicolumn{2}{|l|}{ Panel B: Institutional ownership } \\
\hline Mutual & The ownership percentage of domestic mutual funds in a firm. \\
\hline QFII & The ownership percentage of QFIIs in a firm \\
\hline Others & $\begin{array}{l}\text { The sum of ownership of other types of institutional investors } \\
\text { (including banks, insurance companies, social security funds, } \\
\text { brokers, entrust companies, and financial companies) in a firm. }\end{array}$ \\
\hline Mutuald & $\begin{array}{l}\text { A dummy variable that is equal to } 1 \text { if the firm has domestic } \\
\text { mutual funds as shareholders and } 0 \text { otherwise }\end{array}$ \\
\hline QFIId & $\begin{array}{l}\text { A dummy variable that is equal to } 1 \text { if the firm has QFII as } \\
\text { shareholders and } 0 \text { otherwise }\end{array}$ \\
\hline Mutualcont & $\begin{array}{l}\text { A dummy variable that is equal to } 1 \text { if domestic mutual funds } \\
\text { are the controlling shareholder of a firm and } 0 \text { otherwise. }\end{array}$ \\
\hline Mutualratio & $\begin{array}{l}\text { Ratio of domestic mutual funds' ownership to the largest } \\
\text { shareholder's ownership }\end{array}$ \\
\hline QFIIratio & $\begin{array}{l}\text { Ratio of QFIIs' ownership to the largest shareholder's } \\
\text { ownership }\end{array}$ \\
\hline Mutualdec & $\begin{array}{l}\text { A dummy variable that is equal to } 1 \text { if the ownership of mutual } \\
\text { funds decreases and } 0 \text { otherwise }\end{array}$ \\
\hline QFIIdec & $\begin{array}{l}\text { A dummy variable that is equal to } 1 \text { if the ownership of QFIIs } \\
\text { decreases and } 0 \text { otherwise }\end{array}$ \\
\hline$\Delta$ Mutual & $\begin{array}{l}\text { The change of mutual funds' ownership, which is calculated by } \\
\text { mutual funds' ownership in a given year minus one-year lagged } \\
\text { mutual funds' ownership }\end{array}$ \\
\hline$\Delta \mathrm{QFII}$ & $\begin{array}{l}\text { The change of QFIIs' ownership, which is calculated by QFIIs' } \\
\text { ownership in a given year minus one-year lagged QFIIs' } \\
\text { ownership }\end{array}$ \\
\hline \multicolumn{2}{|c|}{ Panel C: Firm characteristics and corporate governance } \\
\hline Board size (Board) & The natural log of the number of directors on the board \\
\hline Independent directors (Independent) & Proportion of independent directors on the board \\
\hline Leverage & Total debts/total assets in book value \\
\hline Firm size (size) & The natural log of total assets \\
\hline Largest shareholder (Largest) & Percentage of shares owned by the largest shareholder \\
\hline Tobin's Q & Market value/replacement value \\
\hline \multicolumn{2}{|l|}{ Panel D: Firm performance } \\
\hline Return on assets (ROA) & Net income/total assets \\
\hline Stock Return (RET) & Firm annual stock return \\
\hline
\end{tabular}

